\title{
Optimization of English Speaking Skill and English Grammatical Competence of Second Semester College Students in English Literature of Bung Hatta University Through Role-play Technique: Classroom Action Research of English As Foreign Language
}

Mariati and Al Azwad Fauzan

English Literature, Faculty of Humanities, Bung Hatta University, West Sumatera, Indonesia

\section{Abstract}

Optimization of English Communication Skill of second semester students of English Literature program is one of important learning progress to be achieved. They have been endorsed to be better since they had English conversation class in first semester.

Corresponding Author:

Al Azwad Fauzan

alfauzandjaya@Gmail.com

Received: 18 January 2019

Accepted: 24 March 2019

Published: 31 March 2019

Publishing services provided by

Knowledge E

(c) Mariati and Al Azwad

Fauzan. This article is distributed

under the terms of the Creative

Commons Attribution License,

which permits unrestricted use and redistribution provided that the original author and source are credited.

Selection and Peer-review under the responsibility of the First ELEHIC Conference Committee.
Along with English conversation class in first semester, students also learned other competences of English skill such as grammar, writing, listening, and writing subjects. However, applying grammatical feature of English into speaking activity was still a great difficulty for those who took English conversation class in second semester. Most of the students were still difficult to construct their ideas into proper simple English composition utterances. Based on this problem, this research was focused on Optimization of students' English communication skill and their English grammatical competence by applying Role-Play technique in English conversation class of second semester students. This research has revealed that Role-play Technique improves significantly toward students' understanding of Grammatical used in English speaking activity contextually. It was reflected in research field observation and measurement in answering two research questions; how extent Role-pay technique optimized students' English speaking skill and their English grammatical competence and the Factors. It is concluded that Role-play Technique contributes significantly in optimized students' understanding in applying English grammatical competence into English Speaking Skill contextually.

Keywords: Role-play, Grammatical Competence, Speaking Skill

\section{S OPEN ACCESS}




\section{Introduction}

English communication skill is important for students of English Departement in Faculty of Humaniora, Bung Hatta University. Because in the advanced semester, studen's learning activities will be emphasized on analyzing of literary works of English such as Prose, Drama, and Poetry. The early stage for the provision to the advanced semester, they have to adapt four skill of English communication very well such as; speaking, writing, reading, and listening. Nevertheless, acquiring English speaking skill seemed not easy for second semester students of 2017. Based on classroom speaking observation, it was found that the general problem was their basic knowledge about English such inadequate of vocabulary, deficient knowledge about grammatical feature of English, and misspelled while they spoke.

Observing classroom English speaking activity was found that limitation on English vocabulary background knowledge was the crusial problem. This limitedness affected students' activity in English speaking such as they had difficulties in distinguishing some words as a Verb or as a modal auxilary that made them difficult to talk because they did not know the appropriate words to deliver message and sometime they mixed it as they liked based on ideas.

Murtiana says in her research that having a great amount of vocabulary background knowledge is one of the foundamental elements to make students enable to use English more confidently and succesfully as their oral language skill (5). From her opinion, it can be concluded that being able in English speaking must be required with a great amount of vocabulary background knowledge; so that, the learners can speak fluently with good self confident. Unfortunately, classroom observation of speaking activity was shown that there were great adversity of students in stringging the words into English oral Utterances grammatically. Consequently, most of their utterances were incompleted forms. On the other hand, students also had problem in pronouncing. They faced some difficulty to indentify phonemic aspect of English words pronunciation. For this reason, it was quite difficult to identify the ideas of their speaking messages. These problem were happened because they did not get used with target language such as in speaking activity.

In addition, students also dealed with psychology difficulties while they helt up their English speaking activity in the class. Based on classroom speaking activity observation, they worried and and felt embarrassed whenever they had mistake or an error because of the tendency of English speaking pratice. Otherwise, the aspects of transaction of the conversation between students was not good. They did a lot of long term of shifting or 
silent; because, they were not familiar with the function of the words based on grammatical feature of English while conducting spontaneous English speaking performance in the class.

Due the problems of English speaking skill above, classroom English speaking technique used by the lecturer could not give any headway toward students' problem in English speaking. The activity of English converastion just concerned on given conversation through reading aloud and asked students to practice the conversation in pair. This technique seemed to be interesting for the students but it could not give any leverage toward the issue of student's oral skill significantly. Another technique implemented in English conversation was question and answer by doing discussion section about the main idea of the dialogue. As a result, it could not provide the learners wide opportunity of excercise in producing systematic verbal utterances to convey meaning into target foreign language such as English. Otherwise, Pallawa in his research suggests that classroom learning English activity has to involve the learner into the complex process of target language in using the forms and rules of English oral interaction between students; so that, the interaction between students provides the activity of negotiation meaning, decoding, and comprehension (7).

From the techniques of teaching speaking above, it can be assumed that students' English speaking activity just concerned to textual speaking activity. Students just learnt about pronoucing the dialogues and figure out the messeges of the dialogues. Wahyuni says that to make students enable to speak of target language, they have to get involve directly to that language interaction through peer and group works. As a result, students are brought to self exercise in using the language in their own way (9). For these reasons, teaching technique has a great role in providing students wide opportunity to get involve actively in target language interaction; consequently, self exercising of language used can be conducted communicatively.

Improving students' speaking skill, the participant of oral foreign language need convenient teaching technique with speaking problem that had been faced by the second semester students of English Literature Program at Faculty of humaniora in Bung Hatta University. Nunan has proposed that one of the techniques that can be assumed to be able to give enhancement through implementing of Role Play technique. Because Role Play technique emphasizes on the importance of providing foerign language learners of opportunities to acquire language through communication by introducing the learners about range of function and structure and the areas of vocabulary that possibly used in daily conversation of target language and it could enlarge the ability of speaking in any situation (6). 
According to Wahyuni in her research, she says that to solve the problem of English speaking skill, students need to be required with an effective teaching technique that assist students to enhance their ability in using target language. Beside that, teaching technique also facilitates foreign language learner to utilize target language become their language skill in speaking activity (9). In short, to promote students to enhance their English speaking skill, teaching technique has to assist students and facilitate them to utilize English speaking become their oral language skill.

As a result of implementation of role play technique to teach English speaking skill was providing students to exploration of dialy activity in their oral communication activity. Through role play, it could activate their background knowledge and delivered it into their own situational conversation of role play so that they could have good contextual understanding about the aspect of linguistic features of target language such as grammar, vocabulary used, fluency, and natural interaction in speaking.

According to Harmer, role play technique has the distinct advantages for students to improve their English speaking skill (2). Applying role play can motivate them to get involve in spontanous collague oral language interaction of English that provokes their self confidence better to talk their own background information. In addition, role play broadens the word of classroom speaking activity that allows students to exercise wider range of language feature spontanously.

Since role play was assumed to be effective in teaching speaking of English as foreign language, the researcher was going to use this technique in conducting a classroom action research. According to the academic guidance book of English Literature Program of Humaniora faculty of Bung Hatta university about Converation II describes that conversation learning activity has to teach and train the students to speak in simple expresions and contextually. It can be assumed that role play technique was suitable with the goal of learning process in order to enhance the students' English Speaking skill and grammatical competence of second semester of 2017 academic year. The research was conducted to answer research questions as follow:

1. To what extent can role play technique enhance English speaking skill and grammatical competence of second semester students of English Literature Program at Faculty of Humaniora of Bung Hatta University.

2. What factors are involved in enhancing students' English speaking skill and grammatical competence through role play technique of second semester student of English Literature Program in Faculty of humaniora of Bung Hatta University 


\section{Research Method}

The research was a classroom action research (CAR) that concerned on improving student's speaking skill and grammatical competence of English through role play technique where the researcher was involved in practical activity as a lecturer. The participant of this research was the second semester students of English Literature Program in Faculty of Humaniora of Bung Hatta University. There were actually 36 students in that class. The intsruments used in this research were observation sheets, speaking rubric, interview, and field note. The study was conducted on three cycles where each cycle was orginized with plan, action, observation, and reflection.

\section{Result}

The objective of this research was to study to which extent can role play improve students' English speaking skill and the factors are involved in improving students' English speaking skill through role play technique. So that, the researcher carried out research finding explanation with data analysis that were accumulated through data collection by using research instruments in order to determine students' activities, their learning achievement, and to explore students' response about the processes of classroom English speaking activity through role play technique.

To observe students' speaking basic competency, the research was started with giving an initial test by doing students' speaking performance in the class. After conducted the initial test, the mean score was accumulated as a starting point of students' English speaking skill improvement as well as observing basic competency of students' English speaking skill before giving treatment through role play technique. While having speaking performance, the activity was measured through speaking rubric. The data of the initial test can be seen below:

TABLE 1: The Percentage of Students' Initial-Test Speaking Components Score.

\begin{tabular}{|c|c|c|c|c|c|c|c|c|c|c|}
\hline \multirow{2}{*}{$\begin{array}{c}\text { 1eve1 dari } \\
\text { komp onen } \\
\text { skil bercakap }\end{array}$} & \multicolumn{10}{|c|}{ komponen kemapu an berbicara } \\
\cline { 2 - 13 } & \multicolumn{2}{|c|}{ Aksen } & tatabahasa & \multicolumn{10}{c|}{ kosakata } & \multicolumn{2}{|c|}{ lancar } & \multicolumn{2}{c|}{ pemahamanan } \\
\cline { 2 - 12 } & Frek & $\%$ & Frek & $\%$ & Frek & $\%$ & Frek & $\%$ & Frek & $\%$ \\
\hline 1 & 1 & 3 & 0 & 0 & 0 & 0 & 0 & 0 & 0 & 0 \\
\hline 2 & 19 & 48 & 0 & 0 & 2 & 5 & 16 & 40 & 12 & 30 \\
\hline 3 & 16 & 40 & 25 & 63 & 21 & 53 & 17 & 43 & 13 & 33 \\
\hline 4 & 4 & 10 & 14 & 35 & 17 & 43 & 7 & 18 & 14 & 35 \\
\hline 5 & 0 & 0 & 0 & 0 & 0 & 0 & 0 & 0 & 0 & 0 \\
\hline 6 & 0 & 0 & 0 & 0 & 0 & 0 & 0 & 0 & 0 & 0 \\
\hline
\end{tabular}


In conclusion, there were unsufficient of speaking skill; because the percentage of the level was around the lower rank of the speaking rubric. It was between level 1 until level 3 in generally where the utterances of students were in difficult level; because, they had unappropriate productive of spoken English. Mostly, they did frequent errors about the major pattern of the dialogue. Moreover, they were difficult to the delivery the dialogue because of unsufficient vocabulary. As a result, the dialogues were diffuse and difficult for understanding. Therefore, there must be further action implemented to improve the students' speaking ability to overcame students' speaking problem.

\subsection{To what extent role play technique can improve students' speaking skill}

Role play technique for improving teaching and learning speaking gives significant contribution toward students' English speaking skill. This technique improves the aspect of English speaking skill of learners. Role play technique brings the learners in practicing structures and fuctions of target language into their background experiences and knowledge. As a result, role play technique for Speaking skill provides the foreign learners to the domain of personal use of language that had been presented in the early stage of teaching formally. Consequently, role play technique trains English foreign learners in improving the ability of fluency in oral communication.

Cycle one was the first stage of the research to take an action toward the situation of students' problem. The objective of this stage was the problem that displayed at the initial test. The problem was about unappropriate productive of English speaking skill. Mostly, they did frequent errors about the major pattern of the dialogue or sentence. Moreover, they were difficult in delivering the dialogue because of unsufficient of vocabulary. As first cycle, it was organized into four stages namely; plan, action, observition, and reflection. At this cycle, it was conducted onto four meeting by applying role play technique. After conducting the meetings, the progress was observed through giving test which was accumulated into the table 2 below:

From table 2, it can be seen that the distribution of students' speaking components was on the level 2,3, and 4 toward students' speaking components (accent, grammar, vocabulary, fluency, and comprehension). Based on these rating scales level, students still faced some problem which made their speaking interaction caused occasional misunderstanding and interfered the turn taking of conversation.

The first cycle did not have significant improvement on the students' speaking ability. Students' achievement in overally was better than at the initial test. This condition rose 
TABLE 2: The percentage of Students' Speaking Components Score of Cycle 1.

\begin{tabular}{|c|c|c|c|c|c|c|c|c|c|c|}
\hline \multirow{3}{*}{\begin{tabular}{|c} 
leveldari \\
komponen \\
skil \\
bercakap
\end{tabular}} & \multicolumn{10}{|c|}{ komponen kemapuan berbica ra } \\
\hline & \multicolumn{2}{|c|}{ Aksen } & \multicolumn{2}{|c|}{ tatabahasa } & \multicolumn{2}{|c|}{ kosakata } & \multicolumn{2}{|c|}{ lancar } & \multicolumn{2}{|c|}{ pemahamanan } \\
\hline & Frek & $\%$ & Frek & $\%$ & Frek & $\%$ & Frek & $\%$ & Frek & $\%$ \\
\hline 1 & 0 & 0 & 0 & 0 & 0 & 0 & 0 & 0 & 0 & 0 \\
\hline 2 & 10 & 30 & 0 & 0 & 1 & 3 & 2 & 6 & 0 & 0 \\
\hline 3 & 14 & 42 & 18 & 55 & 15 & 45 & 13 & 39 & 7 & 21 \\
\hline 4 & 9 & 27 & 14 & 42 & 17 & 52 & 18 & 55 & 23 & 70 \\
\hline 5 & 0 & 0 & 1 & 3 & 0 & 0 & 0 & 0 & 3 & 9 \\
\hline 6 & 0 & 0 & 0 & 0 & 0 & 0 & 0 & 0 & 0 & 0 \\
\hline
\end{tabular}

up after giving treatment in three types of role play. This progressive was effected by the ideas of role play materials were close to their real condition. This conditions were measured from the clarity of ideas of the dialogue and the topic. However, there were the weaknesses of students' speaking components which were needed to be revised for next cycles.

In cycle two, the researcher concerned on the phenomenon in the first cycle where the students still had some problem for their speaking skill. Most of the students still had uncertain understanding in implementing the features of sentences and the components of speaking. It was found constant errors of major pattern of the dialogue that could prefent the turn taking of speech while performing. A long with grammatical error of basic pattern of speech, most of the students also had problem of words choice of verb alteration that was inaccurate with the idea of the dialogue and grammar. As a consequently, They restrained the burden while they want to talk in English spoken. These burdens came from unsifficient in linguistic knowledge such part of speech, pronounciation, unsufficient of vocabulary.

The researcher improvised role play technique with another form role play. He prepared disordered guided role play technique. Speaking activity was not begun with situational role play only, but he also gave disordered of the dialogues for students' excercise. The aim was to take students into guided linguistic understanding such as part of speech.

After conducting four meetings of cycle two through role play technique, students' speaking English skill seemed to be better than in cycle one. The avarage score was became 20,87 and the rating scales level of students' speaking English components became better; it was around level 3, 4, and 5. At these scales level, there was some progress of students' speaking English skill improvement that can be seen on table 3 below: 
TABLE 3: the Precentage of Students' Speaking Components Score of Cycle 2.

\begin{tabular}{|c|c|c|c|c|c|c|c|c|c|c|}
\hline \multirow{2}{*}{$\begin{array}{c}\text { Level of } \\
\text { speaking skill } \\
\text { components }\end{array}$} & \multicolumn{8}{|c|}{ Speaking skill components } \\
\cline { 2 - 13 } & \multicolumn{2}{|c|}{ Accent } & \multicolumn{2}{c|}{ Grammar } & \multicolumn{2}{|c|}{ Vocabular } & \multicolumn{2}{|c|}{ Fluency } & \multicolumn{2}{c|}{ comprehension } \\
\cline { 2 - 13 } & Frek & $\%$ & Frek & $\%$ & Frek & $\%$ & Frek & $\%$ & Frek & $\%$ \\
\hline 1 & 0 & 0 & 0 & 0 & 0 & 0 & 0 & 0 & 0 & 0 \\
\hline 2 & 0 & 0 & 0 & 0 & 0 & 0 & 0 & 0 & 0 & 0 \\
\hline 3 & 18 & 55 & 5 & 15 & 1 & 3 & 0 & 0 & 0 & 0 \\
\hline 4 & 16 & 48 & 21 & 64 & 16 & 48 & 21 & 64 & 12 & 36 \\
\hline 5 & 0 & 0 & 7 & 21 & 16 & 48 & 12 & 36 & 21 & 64 \\
\hline 6 & 0 & 0 & 0 & 0 & 0 & 0 & 0 & 0 & 0 & 0 \\
\hline
\end{tabular}

From the table above, the level of speaking components were more concerned at level 4. At this level, the decrese of each components of speaking did not interfere clearlyness of utterances in their conversation. The dialogues were still unclear to be listened to; because they did some errors for grammatical features, mispronunciation, and limited vocabularies.

From reflection above, it can be concluded that classroom speaking activity did not give significant progress yet. Form the data analysis of second cycle, it was indicated that most of the students still had a problem of speaking skill with foreign accent. Beside, the problem was also described on grammar error showing imperfect control of some patterns of the dialogue. Afterward, the composition of sentence item of the dialogues were contained unappropriate words choice with the topic and the message of role play. The last problem was hesitant in uttering the dialogue.

Concerning on students' problem in cycle 2, most of the students had difficulties toward their speaking skill. It was reflected on the indicators description of speaking rubric at the test of cycle two. From the data analysis, it indicated that most of the students had still produced foreign accent and mispronunciation. In addition, grammar errors were detected while they had been performing their role play in the class. For these reasons, most of the students were still oppressed by self confident to speak; because, they still dialed with uncertain understanding about basic knowledge of English such as English part of speech, pronunciation, and vocabulary. As a result, their accent was still awkward and led to occasional misunderstanding, and the fluency of role play conversation between students was not smooth.

Based on students' problem description above, the researcher needed to conduct the research to third cycle in order to prevent the weaknesses of students' speaking skill based on students' speaking skill evaluation and assesment. The activities were still the 
same pattern by applying three types of role play such as disordered guided role play, fill in the blank guided role play, and situational role play. Teaching and learning through role play activity in cycle three was conducted onto four meeting and it was going to be devided into plan, action, observation, and reflection.

After conducting four meeting of cycle 3, the testing session was helt up at meeting five of cycle 3. Students were directed to perform situational role play. Students were given situational problem as discussion object of their conversation. From the test activity, it was found that the avarage of students' speaking skill was had good score where they can reach 22 as their higher score. To overview students' speaking development more specifically, it could be seen from the table below. The table describes about the development of the components of speaking skill.

TABLE 4: The Percentage of Students' Speaking Components Score of Cycle 3.

\begin{tabular}{|c|c|c|c|c|c|c|c|c||c|c|}
\hline \multirow{2}{*}{$\begin{array}{c}\text { Level } \\
\text { of } \\
\text { speaki } \\
\text { ng } \\
\text { compo } \\
\text { nenent }\end{array}$} & \multicolumn{10}{|c|}{ Speaking skill Components } \\
\cline { 2 - 13 } & \multicolumn{2}{|c|}{ Accent } & \multicolumn{2}{|c|}{ Grammar } & \multicolumn{2}{|c|}{ Vocabulary } & \multicolumn{2}{|c|}{ Fluency } & \multicolumn{2}{c|}{ Comprehension } \\
\cline { 2 - 13 } & Frek & $\%$ & Frek & $\%$ & Frek & $\%$ & Frek & $\%$ & Frek & $\%$ \\
\hline 1 & 0 & 0 & 0 & 0 & 0 & 0 & 0 & 0 & 0 & 0 \\
\hline 2 & 0 & 0 & 0 & 0 & 0 & 0 & 0 & 0 & 0 & 0 \\
\hline 3 & 18 & 55 & 5 & 15 & 1 & 3 & 0 & 0 & 0 & 0 \\
\hline 4 & 16 & 48 & 10 & 30 & 16 & 48 & 21 & 64 & 12 & 36 \\
\hline 5 & 0 & 0 & 13 & 39 & 16 & 48 & 12 & 36 & 21 & 64 \\
\hline 6 & 0 & 0 & 0 & 0 & 0 & 0 & 0 & 0 & 0 & 0 \\
\hline
\end{tabular}

From table 3 above, it reflected the significant of role play technique for improving English spoken skill. $39 \%$ of students had better understanding about grammar. About 13 students could reach level 5 of speaking rubric for grammar skill. Grammar skill at level 5 indicated that students already had better understanding about structure and function of simple form part of speech in oral communication of English. in role play activity, they already understand about the alteration of verb.

Students' vocabulary background knowledge at thirth cycle was better better than before. $60 \%$ percent of the students were at level 5 . At this level, 18 students already had variety of vocabulary and espression in their dialogues that related to the topic. For fluency and comprehension aspects, $67 \%$ of students could reach level 4 and level 5 . At this condition, 20 students already had smooth speech to express the ideas clearly and logiscally. Automatically, every utterances of role play dialogues could be understood well; however, occasional repetition of the dialogues was required sometime. 
From table 4 above, students' speaking skill was consentrated on score 5 of speaking rubric. The condition of students' speaking achievement was much better. From the description of speaking rubric described that the ability to deliver ideas and messages through oral activity was in the appropriate phase for dialy communication activity. Role play technique helped students to comprehen the aspect oral communication skill such as grammar, vaoculary, fluency, accent, and the ability to comprehen the idea and message.

As reflected on classroom English spoken activities, students' English spoken skill of second semester at English Literature Program at Faculty of Humaniora of Bung Hatta University has improved. This improvement was caused by the implementation of role play technique in every cycles of the research. In particularly, this teaching speaking technique gave good contribution toward the components of English speaking skill. The progresses of students' speaking skill from pre-test and the test of each cycles as the following.

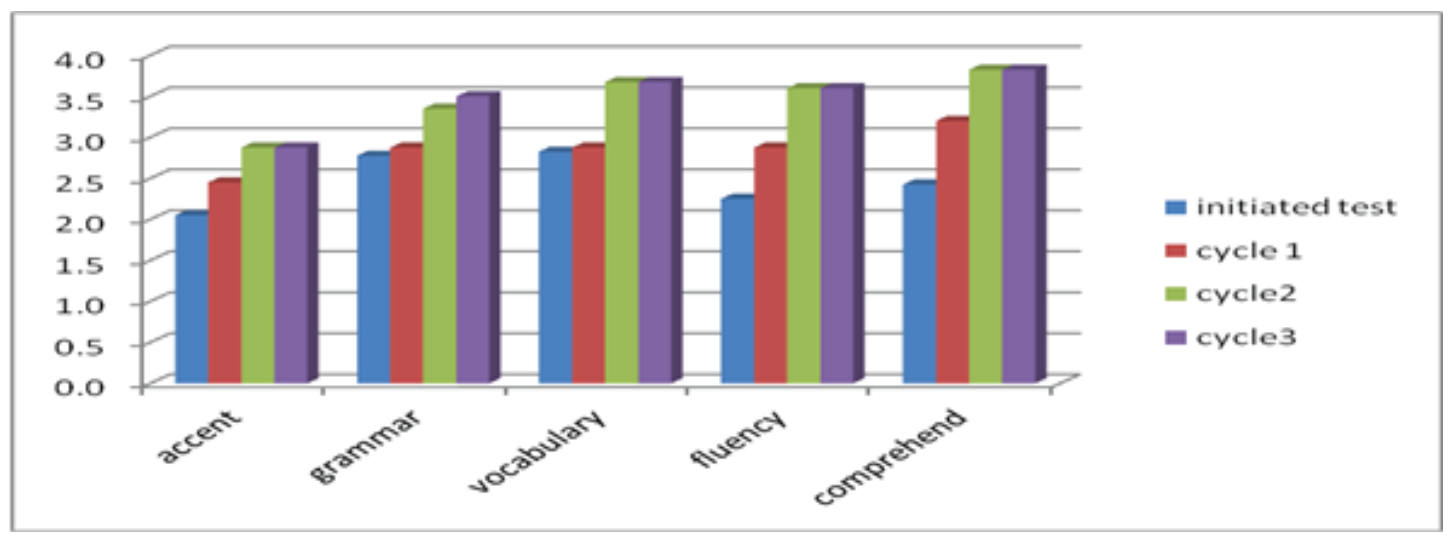

Figure 1: the percentage of Students' Speaking Components Score of Each Tes.

Students' speaking skill improvement was not only displayed from the components of speaking but also refelcted on the score of the test. At initial test, the score was acumulated about 14,93; afterward, the condition was in progress to reach better score up to last thirth cycle. In general, the progress can be seen in the graph below:

It can be concluded that the greater extent of role play technique can improve students' English spoken skill. It can be seen from the result of quantitative data analyzing above at every cycle. The degree of extent was rose up in every cycle. Specifically, it can viewed from initial test and the test of three cycles. From those tests, role play technique bring to a certain extent of the aspects of foreign learners' English spoken such as pronunciation, grammar, vocabulary, fluency, and the ability to comprehen the speech. 


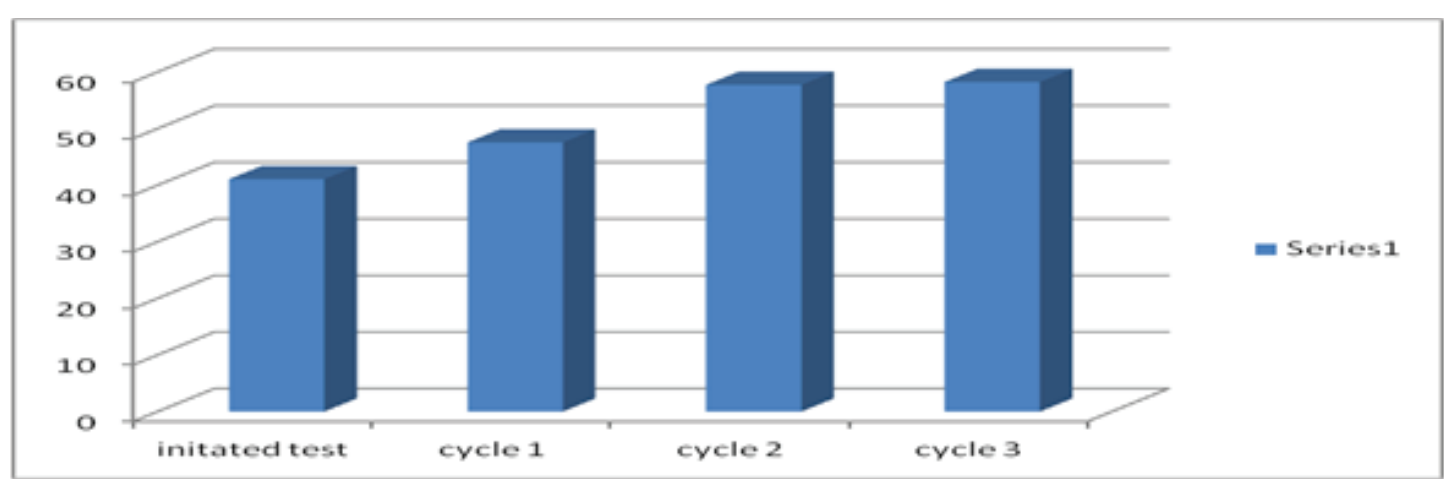

Figure 2: the percentage of average score of speaking of Each test.

\subsection{The factors of students' speaking English skill improvement through role play technique}

Role play as classroom speaking activity can improve students' English speaking skill. Based on data of the research wich conducted in second semester student of English Literature Program at Faculty of Humaniora of Bugn Hatta university, the researcher formulated the factors of students' English speaking skill improvement through role play technique.

Firstly, communicative activity of role play influences the improvement of students' understanding about grammatical feature. They learn the sentence pattern by explanation dan example given contextually. Memorizing of the dialogues was not the object of English speaking activity; but students' utterances were in the right pattern of simple form.

Futhermore, communicative activity of role play also influences the fluency of student when they had role play performance. It made them easier to convei the idea into the dialogue; eventhough, they prefered to express it in simple form of sentence pattern. Automatically, the utterances of dialogues were clear enaough to be understood by speaking partner of the students and the researcher himself.

Another factor of role play technique in improving students' English speaking skill is the role in the conversation. This factor have significant contribution toward the progress of improving students' English speaking skill. It leads English speaking learners into theoretical and contextual understanding of language features of English. For theoretical understanding, the role in the conversation of role play technique brings foreign language learner into practicing linguistic to set a proper part of specch based on the role they are going to play. Automatically, it also helps them to be accurate in using grammar variation and vocabulary properly. 
Last of all, the setting of role play is very important in influencing the improvement of students' English speaking skill. In particular, the setting of role play helps the students to enrich their English speaking skill components such pronounciation, grammar, vocabulary, fluency, and the ability to comprehen. It was displayed on fieldnote of three cycles where most of the students were more active in performing their role play in the class

The benefit of setting in role play is the active phase of learning and offers an opprotunity for students to make personal use of language in a certain situation and place. In preparing their role play dialogue, they have to imagine where the setting is took place. As a result, they are also provided with the task of using exact utterances.

In conclusion, role play technique for teaching English spoken skill toward foreign language learner can give significant improvement. English spoken skill improvement is stimulated by some factors of role play toward the aspects of English spoken skill of college students at second semester in English Literature of Bung Hatta University. Communicative activity factors contributes the aspect grammatical features and the speech fluency because it based on realife activity. The role in conversation factor brings English spoken learners to understand usage and use of grammar, vocabulary knowledge, the ability of speech comprehension. The last is the setting of role play factor. It provides the foreign learner to improvise their enthusiastic to talk in group discussion and performance.

\section{Discussion}

The implementation of role play technique in second semester of English speaking class of English Literature Program at Faculty of Humaniora of Bugn Hatta University that registered 2017 gives an effort in improving students' English speaking skill. Role play technique improves students' achievement of pronouncing, grammatical features, contextual vocabularies used in simple expression of the dialogues, fluency and comprehensible of the students. The improvement can be seen in the mean score of students' speaking activity. The mean score was increased from 14,93 to 17,57 at the initial test to cycle one. Then, in cycle one to cycle two, the mean score was getting better from 17,57 to 20,87 . After cycle two to cycle three, the mean score of students was rose up from 20,87 to 22.

The factors are communicative activity, role in the conversation, and the setting of role play. For communicative activity of role play technique, the students are provided with contextual English speaking activity that closed to their background experiences and knowledges. As a result, the aspect of communicative activity has improved students' 
English speaking skill. Just like Maley says that role play is the active phase of learning and offers an opportunity for students to make personal use of language (3). Indeed, the ability to communicate of English can not be adapted if learning English spoken activity is not concerned on giving wide opportunity to explore the use of language; otherwise, role play technique brings learners to improvise the used of language.

The next factor in improving students' English speaking skill through role play technique is the role in the conversation. It stimulates the learners from passive become active to talk in familiar situation and problem with personal discourse of the students. As a result, it influences speaking fluency of students; because they have alredy known the idea or message of the dialogue. Brown says that role play technique provides the English-speaking learners some rehearsal time so that students can map out what they are going to say (1). It can be assumed that role play technique provides English Spoken learner to get used in utterancing the ideas through proper expression based on the role in the conversation and increase their fluency in English spoken interaction.

Based on research finding, Role in the conversation of role play technique also helps the learners to be more adaptable with language features and lexical items of English. Through the role in the conversationas, it brings the students to the necessity of acquiring certain structurs in English speaking activity and have their understanding the usage and use of English. Just like Maley says that role play lends itself to almost every type: structures, lexis, functions, intonation pattern, and so on (3). It clears that applying role play activity for speaking English is correlated with developing linguistic aspect of communication. It is also proved by Amelis at her research in 2006 toward Economic class of language centre at State Islamic University of Sultan Kasim Riau. From her research finding, role play technique gives significant improvement toward students' low speaking skill and improvises their English spoken skill through role play technique.

Understanding the role in their conversation, they have wide range of time for group work practicing of speech accent of English while they perform role play dialogue in pair. It is correlated with Murcia and Goodwin opinion; they say that role play is the proper media for practicing pronunciation which are fully contextualized, including gestures and body language, and provide a mutitude of opportunities for practicing natural speech (4). It reflected in research field where the learners had to understand the message from the dialogues and analyzed the intonation of the speech and gesture. Moreover, role play performance brought them to natural speech activity.

Through understanding the setting of role play, the students are provided with the practicing of structures and functions that presented by the teacher in early stage of the lesson or the course. Harmer says that by broadening the world of the classroom to 
include the world outside, they ellow students to use a much wider range of language (2).

In conclusion, role play technique orientation is to take language learners to contextual communication activity as well as adapatation of languistic aspect. The factors of students' speaking improvement through role play increases learners' knowledge about linguistic aspect of English for speaking skill of second semester students of English Literature Program at Faculty of Humaniora of Bung Hatta University that registered 2017 academic years. This research finding is also supported by Rosmaliwarni finding that role play technique was more effective than information gap activity for students' speaking skill (8). role play technique give significant effect toward students' motivation and interest to speak English.

\section{Conclusion, Implication, and Suggestion}

\subsection{Conclusion}

Based on research finding, the implementation of role play technique in speaking class improves students' English speaking skill. The primary finding of the research is the extent of students' English speaking skill improvement through role play technique. Another primary finding of the research is the factors of students' English speaking skill imrpovement through role play technique. The factors are communicative activity, the role in conversation, and the setting of role play. Those factors improve students' understanding about grammatical used, to enrich their vocabulary background knowledge, their pronounciation skill; so that, it also improves students' selve confidence and interactive skill in speaking English.

\subsection{Implication}

Research finding implies that role play technique is capable to improve students' speaking English skill. The strength of role play technique in improving students' English speaking skill are communicative activity between students and their background experience, and students' understanding about the role in conversation and the setting of role play. In addition, Weir says that the technique (role-play) can be valid in both face and content terms for a wide variety of situations and the experience of the examination (10). 
The weakness of role play technique is if the role in conversation and the setting of role play is not related with students' background knowledge. The activity of speaking will not be communicatively and it will lead the students into textual speaking activity. Students can not explore their own understanding in english speaking activity.

\subsection{Suggestion}

1. It's suggested to English lecturer who has the problem in teaching speaking to apply role play technique in improving students' speaking skill.

2. It's suggested to English speaking teacher to get a good knowledge about implementation of role play technique.

3. It's suggested to other researcher to conduct other communicative teaching technique to improve students' English speaking skill.

\section{References}

[1] Brown, H. Douglas. (2004). Language Assessment; Principles and Classroom Practices. New York: Pearson Education.

[2] Harmer, Jeremy. (2001). The Practice of English Language Teaching. Los Angeles: University of California.

[3] Maley, Alan.(1990). Role-play Resource Book for Teachers.Oxford: Cambera Press.

[4] Murcia, Marianne Celce. Ed.(1991). Teaching English as a Second or Foreign Language. Los Angeles. University of California.

[5] Murtiana, Rahmila. (2012). “Enhancing Students' Vocabulary Acquisition through Deep Word Processing Strategy". Master of Educcation, Universitas Negeri Padang.

[6] Nunan, David ed.(2003). Practical English Language Teaching. New York: McGrawHill Companies, Inc.

[7] Pallawa, Baso Andi. (2013). "Conversation Strategies Used by Students of the English Department of Tadulako University”. Jurnal Pendidikan Humaniora, 2 (1): 159 - 168

[8] Rosmaliwarmis.(2005). The Effect of Role-Play and Information Gap on Students' Speaking Skill. Master of Education, Universitas Negeri Padang.

[9] Wahyuni, Dewi Sari. (2012). "Improving Students' Speaking Skill by Using Inside Outside CircleTechnique for ET-5/1 Students at LBPP LIA Pekanbaru, Does It Really Work". Classroom Action Research, 5 (1): 165 - 219 
[10] Weir, Cyril J.(1990). Communicative Language Testing. London: Prentice Hall International Ltd. 